\title{
Improving the Journal of Range Management: Some Management Science Philosophy and Ecological Observations By David L. Scarnecchia
}

This paper is a discussion of the paper $A n$ Analysis of the Journal of Range Management: Report of the SRM Task Force published in the June issue of Rangelands (Society for Range Management Task Force on the Journal of Range Management 2003). It is a call to consider some fundamental issues related to the Society for Range Management (SRM), the Journal of Range Management (JRM), and the science that supports them. The matters addressed in this paper are addressed in significantly more detail in papers entitled "Empowering Diversity: Envisioning, Designing and Developing Range Management Science," submitted as a Viewpoint to the Journal of Range Management, and "Viewpoint: Synthesis, Range Management Science, and the Journal of Range Management," in press in the Journal of Range Management.

The principal objective of this paper is to encourage those active in trying to improve the Journal of Range Management to approach the task comprehensively by examining the basic elements of the Society for Range Management and the basic identity of range science, and to develop an integrated solution that (1) addresses root causes rather than symptoms, (2) achieves multiple efficiencies, and (3) accomplishes multiple objectives.

A secondary objective is to ensure that the Board of Directors of the Society for Range Management is, as mentioned in the Task Force's analysis (pg. 13 , col. 1), provided with an array of options (or at least another option beyond the one provided by the SRM Task Force) for improving the Journal of Range Management.

Most of the Task Force's recommendations related to investigations of joint publishing, electronic publishing, electronic indexing, and marketing are straightforward and should be pursued. Also, institutional subscription rates and page charges need to be adjusted, within an overall business plan, to reflect market standards. I cannot cover all of the de- tails of these and other matters, some of which are addressed in the longer papers mentioned previously. I will focus on two recommendations in the Report of the Task Force: the proposed formation of an editorial oversight board, and the exploration of a new range ecology journal.

\section{An Editorial Oversight Board?}

As a move toward improving the vision and content of the Journal of Range Management, the Task Force has recommended "formation of an editorial oversight board independent of the associate editors and composed of SRM member scientists representing diversity of sub-discipline and seniority, to focus the subject matter of JRM content." Members of the SRM Task force to improve the Journal of Range Management are currently assembling the oversight board. By the time this paper is read the board will likely be in place. Current members of the JRM Editorial Board will be represented on the editorial oversight board, and members of the Task Force to improve the Journal will likely be strongly represented on this board. Formation of the editorial oversight board effectively removes responsibility from the technical editor and associate editors for judgments of vision and content of the Journal. The Board of Directors should carefully consider the implications of any decision to remove that responsibility.

Because a move to this hierarchical arrangement represents a diminution in authority and responsibility of the technical editor and associate editors, it should be decided as part of a comprehensive decision that includes the kind of publishing (i.e., internal or joint) that the Journal wants to pursue in the future. A move to external or joint publishing of the Journal would significantly change the role of the technical editor from more mechanical matters more toward matters of vision and content. In that case, the roles of the technical editor and the editorial oversight board would likely overlap, possibly to the point of redundancy. 
The current technical editor, to his credit, has functioned without the benefit of coherent guidance from the SRM leadership in matters of vision and scope, and instead has been forced to satisfy fragmented, special, and often competing interests regarding the character and content of the Journal of Range Management. The oversight board, either alone or preferably with the guidance of the SRM Board of Directors, will need to provide the editor with concise, coherent guidelines if it does not want the technical editor to make these judgments.

In any case, in the absence of a coherent vision from the SRM Board of Directors, the editorial oversight board will need to resolve some basic issues related to the Society, the Journal and the science. It will need to resolve, among other issues, (1) the essence and scope of the science supporting the Journal of Range Management, (2) whether to broaden the diversity of content and the kinds of papers in the Journal or narrow the diversity of content and the kinds of papers, (3) whether to retain or change the name and mission of the Journal.

If the oversight board, or SRM leadership is to effectively address the many issues and challenges facing the Journal of Range Management and the Society for Range Management, it will be most effective if it designs or adopts a comprehensive plan that (1) effectively utilizes to advantage the natural diversity of scientists and other technical professionals in the Society for Range Management membership, (2) addresses multiple objectives and synergies simultaneously within the science, the Society, and the Journal, and (3) makes interpretive, ecological-style judgments in harmony with naturally evolving trends within the science, the Society and the Journal, rather than forcing agricultural-style judgments to treat specific symptoms of problems with those entities.

In the previously mentioned papers, I recommended developing a broadly interpreted management science concept of range science, which led to numerous integrated recommendations to improve the Journal including (1) significantly diversifying our concept of research to be considered for publication in the Journal of Range Management, (2) increased recognition of the importance of synthesis in range management science, (3) further expanding the international dimensions of the Journal of Range Management, (4) renaming the Journal of Range Management the International Journal of Range
Management Science, and (5) developing precise language to describe our science, our management discipline, our range professionals, and the scope of what the word range means. I cannot reproduce all of those analyses here, but instead will pursue some of the basic rationale behind these recommendations by examining the second of the SRM Task Force's two main recommendations - that of exploring development of a new journal of range ecology.

\section{A New Journal?}

The JRM Task Force's recommendation to explore "a new ecological journal to engage current SRM-member authors who publish in and read primarily other journals, to attract former SRM-member scientists, and to attract new members from the ecological sciences" should be questioned. I give seven reasons in one of the previously mentioned papers (Scarnecchia in review) for not pursuing a new journal at this time. Three stand out.

First, as the JRM Task Force has noted, the publishing environment in ecology has become highly competitive, and includes numerous, more prestigious options for publishing. Because ecological scientists are strongly driven by peer pressure to publish in prestigious outlets, an upstart journal of the Society for Range Management is unlikely to become a preferred outlet. The success of a new journal is not assured.

Second, removal of the papers in experimental ecology would damage the diversity of the current Journal of Range Management, which is currently a functioning and lucrative publication for the Society for Range Management. Ecological papers are, notwithstanding the reduced numbers of them noted in the Task Force report, still an essential element of the Journal's content. Their removal to provide content for a new ecological journal would certainly damage the current Journal's diverse content, and could adversely affect its finances and its prospects. If the Task Force's analysis includes the conclusion that the gradual loss of ecology papers has been a problem for the Journal of Range Management, the removal of all such papers from the Journal would be an acute problem.

Third, and most importantly, the defection of range ecology into a separate journal leaves range science with an undefined, fragmented identity that undermines the hugely underutilized strength available in its diversity. Development of a new journal does not 
solve, and indeed exacerbates, the long-standing, largely unspoken dispute over what is the core of range science. The Task Force report suggests, in several places, (e.g., pg. 16, col. 1) that range ecologists are the "core" scientists of the SRM. This view, outside of the heavily ecologist-laden Task Force, is certainly not a consensus view among the Society's diverse membership of scientists and other technical professionals. In any case, removal of range ecology from the Journal would effectively fragment and factionalize the science and the Society for Range Management. It would encourage a continued weak identity for range science, with numerous disadvantageous consequences for the Society for Range Management, for range science programs at the land-grant universities, and for individual range professionals (Scarnecchia in review).

The leadership of The Society for Range Management has been slow to rigorously define an effective, diverse, inclusive identity for range science. As the disciplinary environment of the natural sciences has become increasingly competitive in recent years, range science, to survive as a living entity within an increasingly competitive environment, has responded with ecological predictability. Range science as a science has been evolving to fill the most available ecological niche.

The implications of this evolution of range science for the JRM Task Force's analysis are profound. Those range ecologists that have left the Journal of Range Management, rather than leaving the Journal by agricultural-style force, have departed voluntarily by ecological-style dispersion. Trends in the subject matter of The Journal of Range Management and range science have not been molded with business-style executive direction; they have evolved more-or-less naturally in response to market or quasi-market forces. So the trends in the data generated and analyzed by the $J R M$ Task Force are our best indicators of where the Journal of Range Management needs to go. In a sense, it is showing us where it needs to go, and we, as individuals, as a Society, or as a Task Force, should see that. Range science, as indicated accurately by the Journal of Range Management, has not found a home in any specialized science, including ecology. The science, through the Journal, is telling us that. We should, to paraphrase Thadis Box, listen to the landscape. The Task Force's recommendation to dissect the Journal of Range Management in pursuit of a new ecological journal, ironically the product of ecologists, lacks ecological merit, and instead more resembles the kind of forced agricultural single-mindedness that the Task Force implicitly disdains throughout its report.

Range science, as indicated by the activities of range professionals, and trends in the Journal of Range Management, is telling us that for its survival, and notwithstanding frequent attempts to commandeer it for specialized objectives (e.g., grazing, or ecology), it is evolving into a highly diverse management science. The demand for range science as a specialized science, and for range management as a specialized management discipline has been decreasing. Increasingly, range professionals, both scientists and technical personnel, are dealing with complex, analytical management problems of people and landscapes involving many variables, multiple objectives and multiple efficiencies.

The disciplinary trends have, in most respects, moved in advance of the science (as represented by the content of the Journal of Range Management) because the Journal has, to a significant degree, resisted the natural evolution of range science into range management science through editorial policies that discourage certain kinds of research papers. While the Task Force's data indicate that the number of ecology papers in the Journal has decreased in the past ten years, my impression, and I think the impression of many other individuals, is that the technical quality of experimental research papers in the Journal of Range Management has, largely because of the efforts of the technical editor and associate editors, improved significantly. I have seen little evidence that experimental ecological research has been discriminated against by the Journal of Range Management. More frequently, experimental grazing research has been, however justifiably, disfavored because of sampling deficiencies or problems of uncontrolled variables.

But more importantly, for several decades now, the Journal of Range Management has been largely unreceptive to conceptual or design-oriented papers, theoretical papers, or modeling papers that are not data based. Much of the pressure to exclude these papers has come from experimental scientists who have been associate editors on the Editorial Board of the Journal of Range Management. Notwithstanding the Task Force's synonymous use of the terms SRM scientist and SRM ecologist in parts of their analysis (e.g., pg. 16, col.1), experimental scientists, including ecological scientists, are not the only scientists in 
the Society for Range Management. In any case, the result has been an unnatural restraint of diversity of the kinds of papers published in the Journal of Range Management, and to the extent that the Journal has defined the science, delay of the conceptual development of range management science.

Such a narrow editorial philosophy, based on a narrow conception of what constitutes research, may be effective for a specialized journal like the Agronomy Journal, but has been hugely counterproductive to a defining journal of a science like range science that is trying to evolve into a diverse management science. Experimental research is only one kind of research within management science. Theortical and other conceptual research are essential to advance the science. Also, for range science, as range management science, to help technical professionals interpret, analyze and solve complex management problems, we will need a broad view of what constitutes research in range management science. Otherwise, management personnel will be on their own in designing management approaches (e.g., coordinated resource management), as they have been in the past, and still are today. This unfortunate situation exists today partly because range science is effectively at least 30 years late in integrating its fragmented branches into a philosophically coherent, technically integrated management science.

In some way, the data and interpretations presented in An analysis of the Journal of Range Management: Report of the SRM Task Force exemplify the inherent limitations of experimental science in addressing complex management problems like, for example, managing the Journal of Range Management. Improvement of the Journal of Range Management, like nearly all of the problems range professionals face, is a management science problem; it needs to be addressed systematically with a combination of empirical and conceptual analyses. The Task Force's analytical report is a good example of empirical (observational) research in the absence of guiding interpretive theory. Such analysis frequently leads to treatment of symptoms rather that treatment of basic, underlying problems.

We need to immediately modernize the management, electronic indexing, and electronic delivery of the Journal as outlined in the report. Institutional subscription rates and page charges need to be adjusted, within the constraints of an overall business plan, to bring the Journal into line with its competitors. But before the new editorial oversight board pursues exploration of a new journal or sets editorial policy for the existing Journal of Range Management, the Society needs to resolve basic issues related to the identity and character of the Society for Range Management and the science that supports it. I hope that these issues will be resolved with actions more resembling the interpretive guidance characteristic of ecology rather than the dogmatic force characteristic of agriculture. If we listen to the landscape, we will hear the diversity and integrated coherence of an inclusive range management science.

Even though we are thirty years late in developing range management science, we still have an excellent opportunity here to envision and develop it. The program at the Society for Range Management Meeting in Casper is indicative of the diversity of the Society, the science, and the profession, and of the potential scope of what range is. We need to encourage more scientists, including ecologists, to publish in the Journal of Range Management, but should avoid fragmenting the Journal or the Society in narrowly conceived attempts to address specific symptoms rather than underlying problems. The Journal needs to operate with a broader concept of research, and with expanded recognition of the importance of diversity and synthesis in range management science. We should include and empower the diversity within the Society with philosophical coherence and technical integration; and instead of forcing changes contrary to natural trends in the science or the Journal, or just drifting where natural forces lead us, we should move ahead with ecological-style awareness, precise language, and creative management science.

Author is Associate Professor, Department of Natural Resource Sciences, Washington State University, Pullman, WA 99164-6410, and Book Review Editor, Journal of Range Management and Rangelands.

\section{Literature Cited}

Scarnecchia, David L. In review. Viewpoint: Empowering diversity: Envisioning, designing and developing range management science. J. Range Manage.

Scarnecchia, David L. 2004. Viewpoint: Synthesis, range management science, and the Journal of Range Management. J. Range Manage. In press.

Society for Range Management Task Force on the Journal of Range Management. 2003. An analysis of the Journal of Range Management: Report of the SRM Task Force. Rangelands. 25(3):13-22. 

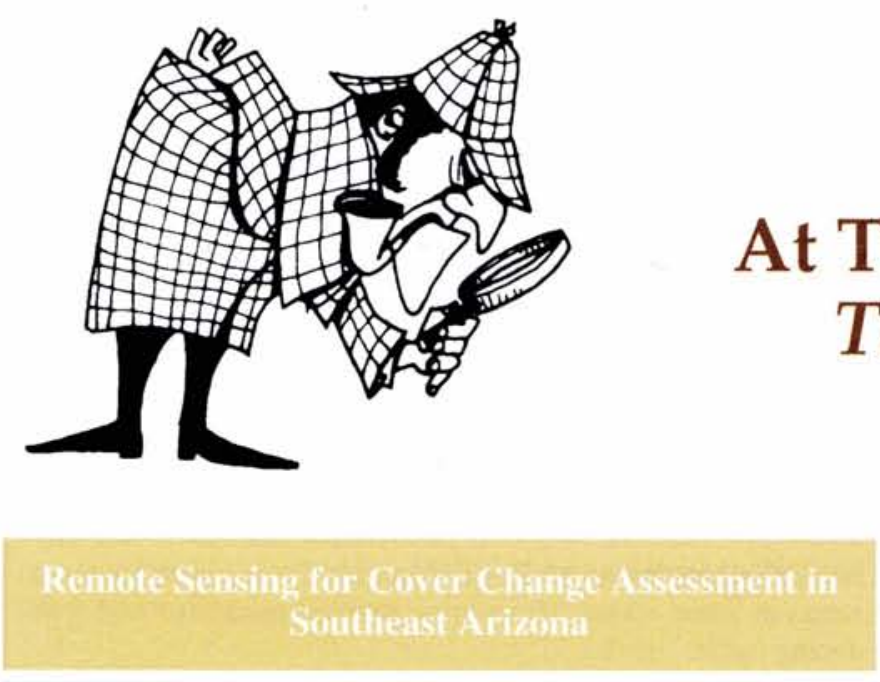

Osman C. Wallace, Jiaguo Qi, Philip Heilman, and Robin C. Marsett

Understanding landscape conversion is vital for assessing the impacts of ecological and anthropogenic disturbances at regional and global scales. Satellite data were used to quantify land cover change and to relate spatial configuration and composition to landscape structure and pattern. Results indicate that in rural areas, homogeneous shrubs and mesquite are replacing grass, whereas in the urban areas, grass as well as shrubs and mesquite are converting to a fragmented and expanding built landscape. The cover change assessment is conducted for aiding in the development of sustainable land use practices, successful regional planning, and effective policy implementation.

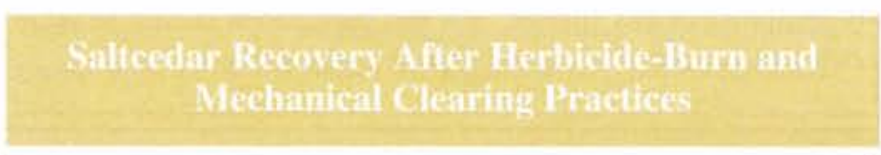

Kirk McDaniel and John P. Taylor

Saltcedar are exotic trees that prevail in monocultural thickets and in mixed riparian communities along the Rio Grande on the Bosque del Apache National Wildlife Refuge, Socorro, N.M. This 6-year study examined salt cedar recovery after herbicide-burn and mechanical clearing practices. Both treatments provided $>90 \%$ saltcedar control but cost for mechanical clearing were nearly 6 times higher than aerial spraying followed by prescribed burning. Saltcedar removal is an important first step in the process of riparian restoration, but ways saltcedar were removed in this study were shown to influence later riparian community development.

\section{Sneek A Peek} The Journal Of Range Management

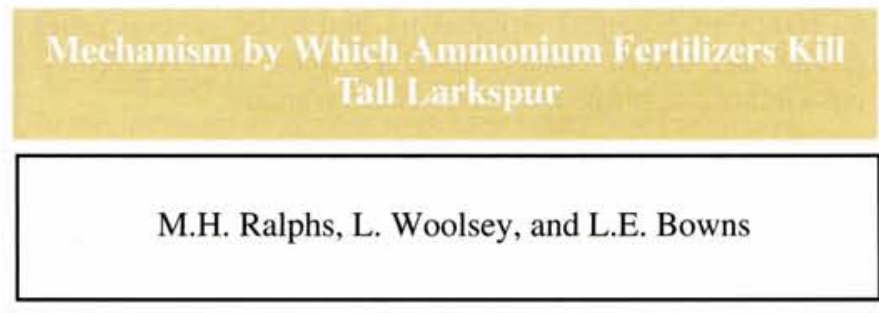

Environmental concerns of using pesticides on public lands have greatly reduced the use of herbicides to control tall larkspur. Fertilizers have been reported to control larkspurs, so we determined the mechanism by which nitrogen fertilizers kill tall larkspur. Results suggest that it is the salts in ammonium sulfate and ammonium nitrate that kill larkspur, and that the fertilizer must be concentrated at the base of the plant rather than broadcast. The relative cost of materials per plant for both ammonium sulfate and nitrate was $12.9 \notin$, and $2.6 \notin$ for salt

\section{Douglas A. Johnson, Nicanor Z. Saliendra, John W.} Walker, and John R. Hendrickson
Because they are so expansive, sagebrush-steppe rangelands could be important in the global carbon budget. It is important to know if different methods for determining $\mathrm{CO}_{2}$ fluxes give similar values. The Bowen ratio-energy balance and canopy chamber techniques for measuring $\mathrm{CO}_{2}$ fluxes were compared across 4 years on a sagebrush steppe site near Dubois, Idaho. Despite differences during the late-summer period, the 2 techniques were significantly and positively correlated during the early, mid-, and late season periods so that both techniques can be used to monitor $\mathrm{CO}_{2}$ fluxes on sagebrush steppe rangelands. 


\section{Wyoming Bits Saschrush Sccd Production Fyom Mitred and Uthomined Rangelands}

\section{D.T. Booth, Y. Bai, and E.E. Roos}

We measured sagebrush seed production on mined land and on adjacent undisturbed rangeland near Glenrock, Wyoming, to determine relative yield, quality, and effect of wildlife. We also tested methods to increase seed production. Mined-land sagebrush protected from wildlife (fenced) had greater seed production, and equal or better seed quality, than sagebrush from unmined land. We conclude sagebrush seed-production potential on mines such as this is equal to, and often several times greater than, that of adjacent un-mined lands; however, browsing wildlife can negate the mined-land advantage.

\section{Spatinl and Temporal Patterms of Catte Rece Beposition on Rangeland}

\section{Kenneth W. Tate, Edward R. Atwill, Neil K. McDougald, and Melvin George}

The spatial and temporal pattern of feces deposition by cattle is an important factor in assessing the risk rangeland beef cattle production poses to water quality. Daily cattle fecal deposition patterns across an annual rangeland in Madera County, California were evaluated trom 1995 through 1998. Cattle feces distribution patterns were significantly associated with location of livestock attractants, slope percentage, slope aspect, hydrologic position and season. There are opportunities to reduce the risk of water quality contamination by strategic placement of cattle attractants.

\section{Ficonomic Implications of OTf-Siream Watc Developments to Improve Riparian Grazing}

Amy M. Stillings, John A. Tanaka, Neil R. Rimbey, Tim DelCurto, Patrick A. Momont, and Marni L. Porath

The effect of off-stream water and salt on livestock distribution and riparian area use is an important management issue on both private and public lands. The economic and ecological impacts of this cattle management practice on riparian area utilization was evaluated in northeastern Oregon. When offstream water and salt were used, cattle were more evenly distributed, consumed more upland forage, gained more weight and did so with greater expected annual net returns. Using offstream water and salt to improve cattle distribution away from riparian areas appears to be a profitable tool.

\section{Werche, Nitrogen and Ploids Difects on Rustin Whid ige. Minchal Goncentration.}

J.F. Karn, A.B. Frank, J.D. Berdahl, and W.W. Poland

Little is known about mineral concentrations critical to livestock production in the relatively new tetraploid Russian wildrye plants. Critical mineral concentrations in leaf and stem tissue of Russian wildrye plants as affected by ploidy level, growing season water and $\mathrm{N}$ fertilization were evaluated at different stages of maturity in central North Dakota. Fertilizer N increased forage concentrations of $\mathrm{Ca}, \mathrm{K}, \mathrm{Cu}$, and $\mathrm{Zn}$, and decreased $\mathrm{P}$, while the effects of ploidy level and water were minimal. Concentrations of $\mathrm{P}, \mathrm{Ca}, \mathrm{Mg}$ and $\mathrm{Cu}$ in either leaves or stems at some stages of maturity were marginal for high producing cattle.

itrogen Pertifination and Row Spacing on Digilar exantha Production and Digestibility

Alfredo O. Gargano, Miguel A. Adúriz, Carlos A. Busso, and María I. Amela

Research on the effects of the rate and method of fertilizer application or row spacing on aboveground growth and quality of perennial forage crops is scarce or has produced contradictory results. The effects of $\mathrm{N}$ fertilization rates, method of fertilizer application and row spacing on dry matter yield and digestibility were determined in Digitaria eriantha. Row spacing did not affect dry matter yield. Nitrogen application should be between 50 and $100 \mathrm{~kg} \mathrm{ha}^{-1}$ to increase dry matter production or digestibility in this species, and this application should be split rather than applied all at one time in early spring

\section{Defolintion Defrects on Reproductive Biomas Importance of Seale and Tining}

\section{Michael T. Anderson and Douglas A. Frank}

There is a conflict concerning how defoliation affects plant seed production. The effect of migratory ungulates on seed production was evaluated on the northern winter range of Yellowstone National Park. Grazed plots had twice the number of reproductive tillers and greater reproductive biomass per unit area than ungrazed plots, while seed production of individual plants was not different between grazed and ungrazed plots. The scale of measurement, plant versus plot, and timing of defoliation best explain our findings; a large literature review confirmed the importance of these mechanisms in the literature. 


\section{on-Selective Grazing Impacts on Soil Properti the Nama Karos}

Petrus C. Beukes and Richard M Cowling

Non-selective grazing is a high- intensity, low-frequency grazing system used in the Nama Karoo of South Africa. The impact of this grazing system on soil organic carbon, soil microbial respiration rates and soil stability and infiltration properties were evaluated over a 3-year period. The grazing system resulted in a more active microbial community which turned over the organic matter more rapidly and led to higher soil stability and infiltration capacity of open unvegetated soils. There are conditions where herding high densities of large herbivores can have positive impacts on soil quality.

\section{Lerify Spurge Control in Western Prenivie Puinges Orditid Thatifar}

Donald R. Kirby, Rodney G. Lym, John J. Sterling, and Carolyn Hull Sieg

Invasion by leafy spurge is a serious threat to western prairie fringed orchid habitat. A study in southeastern North Dakota evaluated the effect of herbicide treatments to control leafy spurge while sustaining western prairie fringed orchid populations and subsequent soil seedbank composition to guide longterm management strategies. The orchid reoccurrence and density were unaffected by any of the herbicide treatments 1 year after treatment, But over 50 plant species including leafy spurge were identified in the soil seedbank. The dominance of leafy spurge in the soil seedbank following herbicide treatments indicates a long-term management program is required.

Obserwations of Cartile DSe of Prativie Dog Town:

Debra A. Guenther and James K. Detling

Black-tailed prairie dogs greatly alter vegetation and share many preferred forage species with cattle, leading to speculation about competition between these species for forage. Use of prairie dog towns by cattle was investigated on the shortgrass steppe of northeastern Colorado from late May through midAugust, 1999. There were no differences between cattle foraging rates on swales compared to prairie dog towns. Cattle on the shortgrass steppe appear to use the prairie dog towns approximately in proportion to their availability and graze there as intensively as on habitats not inhabited by prairie dogs.

\section{Dffects of Acration on Phenolic Amin Content of Ginsillt}

Steve K. Windels, David G. Hewitt, and T. David A. Forbes

Aeration to reduce shrub cover and increase biomass of palatable forages may increase toxic secondary plant chemicals. The effect of aeration treatments on concentrations of tyramine and N-methyl-B-phenethylamine (NMP) in guajillo was evaluated. Aeration increased NMP but not tyramine concentration in mature stems, stimulated production of juvenile stems that had greater amine concentrations than mature stems, and resulted in amine concentrations that peaked in summer and early autumn when herbivores rely heavily on browse. Aeration may result in higher nitrogen concentrations in guajilo but increases in amines may limit benefits to herbivores.

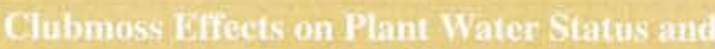
Sfanding (OF)

Tyler J. Colberg and J.T. Romo

Many range managers believe clubmoss competes with grasses for water or intercepts precipitation and negatively affects plant water relations and productivity. The effects of clubmoss on leaf xylem water potential of Junegrass and blue grama was evaluated near Saskatoon, Saskatchewan. The hypothesis that clubmoss reduces productivity of associated plants by increasing water stress was rejected. Range managers should maximize the effectiveness of precipitation instead of reducing or attempting to eliminate clubmoss.

Avarolyzahleand Condenced Thmmins in Mhantso

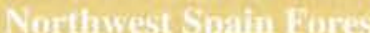

\section{M.P. González-Hernández, J. Karchesy, and E.E. Starkey}

Tannins are secondary metabolites that may affect browsing and grazing on plants. The hydrolyzable and condense tannins in 30 plants in northwest Spain forests were analyzed. Many forage species contain significant levels of astringent tannins with the potential to greatly reduce the availability of protein for livestock and deer with digestible protein a limiting factor in forest communities containing predominantly. Tannins are secondary metabolites that may affect browsing and grazing on plants. The hydrolyzable and condensed tannins in 30 plants in northwest Spain forests were heathers, especially if grasses or forbs are not available. These plant communities are more limited in the digestible protein available than oakwoods and shrublands which consist mainly of gorse or broom. 
Beonomies of Sale Weight. Herd Size.

Supplementation, and Seasonal Factors

Russell Tronstad and Trent Teegerstrom

Quantifying the rate of gain for a calf on the range is critical for evaluating the profitability of different production protocols and market strategies. Tradeoffs between calf sale weights and cow numbers, seasonal forage and price conditions, supplemental feeding, and the price spread between light and heavy calves were evaluated for 2 ranching regions in Arizona. Heavier sale weights were not sufficient to overcome lower prices for yearlings. The most profitable calf sale weight and supplemental feeding strategy was found to differ marginally for the 2 regions.

Chameterization of Diversify among three Syuirreltail Thxa

T.A. Jones, D.C. Nielson, J.T. Arredondo, and M.G. Redinbaugh

Squirreltail is a complex of five taxa whose systematic interrelationships are uncertain and ecological amplitudes are poorly understood. An analysis of several ecological and physiological traits of materials collected in the 10 contiguous western states described variation between and within Elymus elymoides ssp. elymoides, E. elymoides ssp. brevifolius, and E. multisetus. These taxa were found to be ecologically distinct from each other, and three distinct groups of accessions were found within E. elymoides ssp. brevifolius. These results highlight the highly ecotypic nature of the squirreltails, suggesting that restoration practitioners should match site with genetically and ecologically appropriate squirreltail material.
Comparison of Two Technigus for Nonitoring Vegetation on Militany Lands

C.W. Prosser, K.M. Skinner, and K.K Sedivec

The U. S. Army Land Condition Trend Analysis Program is being used on Army installations worldwide, but it may not accurately depict species diversity and composition. The Program was compared with quadrat sampling techniques on a military installation in the transitional grasslands between the tall and mixed grass prairies in east-central North Dakota. The military sampling program did not detect a third of the plants, was labor intensive and time consuming. There is a need to re-evaluate the program across the various ecosystems worldwide to determine if the Army's sampling technique is adequate to make long-term management decisions on military installations.

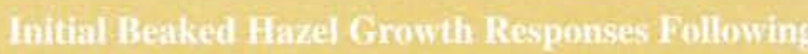 Protection from Ungulate Browsing}

Jody N. Best, Edward W. Bork, and Norm Cool

Despite the importance of beaked hazel for ungulates in western Canada, little information exists on the response of this shrub to intensive wildlife herbivory. This study compared changes over 2 years in beaked hazel stem morphology (total twig length and number) and current annual growth in browsed shrubs, with shrubs recently protected from herbivores in Elk Island National Park, Canada. Although results varied among sites, beaked hazel stems generally increased in growth with protection. Additionally, documented changes at the shrub stem level did not match those of the plant community, suggesting observed responses vary with the scale of measurement.
James A. Young and Charlie D.Clements

Recruitment of seedlings of native willow species is desirable for the restoration of riverine riparian areas following mechanical, herbicidal, or biological control of invasive tamarisk. The germination characteristics of seeds of tree willow and coyote willow at a wide range of constant or alternating incubation temperatures were evaluated. The germination responses and overlapping phenology of these 2 species are very similar meaning they probably compete for germination safesites. The management of riverine willow populations to enhance seedling recruitment is obviously a very complex undertaking. 